\title{
Typologies of Peri-Urban Klaten-Central Java: A study based on Socio-Economic Perspective
}

\author{
Submitted: 19 March 2014 \\ Accepted: 12 August 2014 \\ Reny Yesiana \\ Diponegoro University, Semarang, Indonesia \\ zuren_yess@yahoo.com
}

\begin{abstract}
Urbanization as a socio-economic change in developing countries has been leading to the existence of a region with a mixture of rural and urban character so called Peri-Urban Areas (PUA). PUA has been emerging as a part of urban growth process as well as rural growth, regarded as rural-urban transition. This phenomenon could be clearly observed in Klaten District, Central Java Province. Located between two strategic cities in Central Java, i.e. Yogyakarta and Surakarta, Klaten has been experiencing a significant land conversion (among the highest in the province) and a significant economic growth in comparison to other districts in the province. Accordingly, Klaten was chosen as the case study to understand the PUA development in Central Java. By focusing on socio-economic perspective, this paper aims to determine PUA typology in Klaten and further analyze the driving factors of the emerging PUA typology. Quantitative analysis using GIS tools and scoring method was applied to create the typology based on secondary socio-economic data taken from statistics report. As the results of the analysis, it has been shown that most of villages in the study area are highly rural in terms of social character. On the contrary, in economic aspect such as employment, the PUA of Klaten community has a strong urban character. It is classified as the fourth typology (highly rural in social character and highly urban in economic character) among the four identified PUA typologies in Klaten. The underlying influential factor of the development of PUA in Klaten is very much its local potential, i.e. the local economic activity. This may provide an evidence that urban and rural growth could be taken place as a part of 'local' growth which does not necessarily take place as a part of urban growth (expansion) of the main city (growth center).
\end{abstract}

Keywords: Urbanization, Peri-Urban, Klaten

\section{Introduction}

There are various things attributed to urbanization. In one perspective, urbanization is considered as a demographic phenomenon, defined as the degree of urbanity of a community or nation, measured by the proportion of urban population over the total of national population. In wider perspective, urbanization is not only applied in terms of the demographic attribute, but rather as the transformation of agricultural and rural life to an industrial and urban based society as this greatly emphasizes on the process of socioeconomic changes (Firman, 2007).

Pacione (2001) reveals that urbanization in developing countries has a different character from that which has been happening in developed countries. There are several things that have been leading to the differentiations: (1) urbanization in developing countries occur in lower economic growth, (2) migration in developing countries is likely to be very intensive, (3) less industrialization compared to the urbanization rate in most developed countries as it has caused the significant number of unemployment in urban areas. This shows that the history of urbanization in developing countries have reversed the assumption of urbanization theory that has been built based on the experience of developed countries. These countries have experienced intensive industrialization and the urban expansion derived mainly from the industrialization activities in the urban regions. In fact, the industrialization rate in developing countries growth very slowly mainly in comparison to urbanization rate. It may provide indication that the pattern of urbanization does not have to be linear with industrialization such as in developed countries (Damanik, 2003).

Focusing urbanization as the process of socio-economic changes, urbanization in developing countries have led to the emerging region with a mixture of rural and urban character so called Peri-Urban Areas (PUA). PUA has been emerging as a part of urban growth process as well as rural growth, regarded as rural-urban transition. Several changes happened in terms of life style as well as transformation from agricultural to non-agricultural livelihood which will impact to the declining agriculture productivities. Yunus (2008) said that PUA can determine urban life. It means that overall of new physical form of development will occur in this area, so the fabric of urban life on the future can be determined by the typology, process, and the impact that happened in this PUA. Therefore, special attention is needed to the development of 
PUA. As described by McGee (1991) in his theory Asiatica Euphoria, spatial structure of cities in Asia and the surrounding that consists of six components, namely (1) major cities, (2) urban peripheries, (3) ruralurban, (4) dense populated rural, (5) sparsely populated frontier (6) smaller cities and towns. In this discussion of the PUA, the term used by McGee is the area around the city (urban peripheries).

This paper aims to determine PUA typology in Klaten and further analyze the driving factors of the emerging PUA typology focusing on socio-economic variables. There are several perspectives to determine the typologies of PUA. Yunus (2001) determine PUA's typologies based on spatial variable (land use), while Singh (2011) uses several variables, which are spatial variable (population density) and socio-economic variable (occupation, sex ratio, literacy, growth rate).

\section{Research Area and Methodology}

Klaten consists of 26 sub-districts with total area of $65.556 \mathrm{Ha}$ (Klaten in Figures, 2011). The capital of Klaten is Klaten City, including The North, Central, and South Klaten. The focus in this research is PeriUrban Area (PUA) in Klaten which are inside and outside the Yogyakarta - Solo corridor. The delineation of PUA consists of the villages that have city status in each district. There are 16 districts (117 villages) that have cities status. The PUA in Klaten are divided into 3 types:

- DK : within Yogya-Solo corridor

- LKU: outside Yogya-Solo corridor (The North)

- LKS : outside Yogya-Solo corridor (The South)

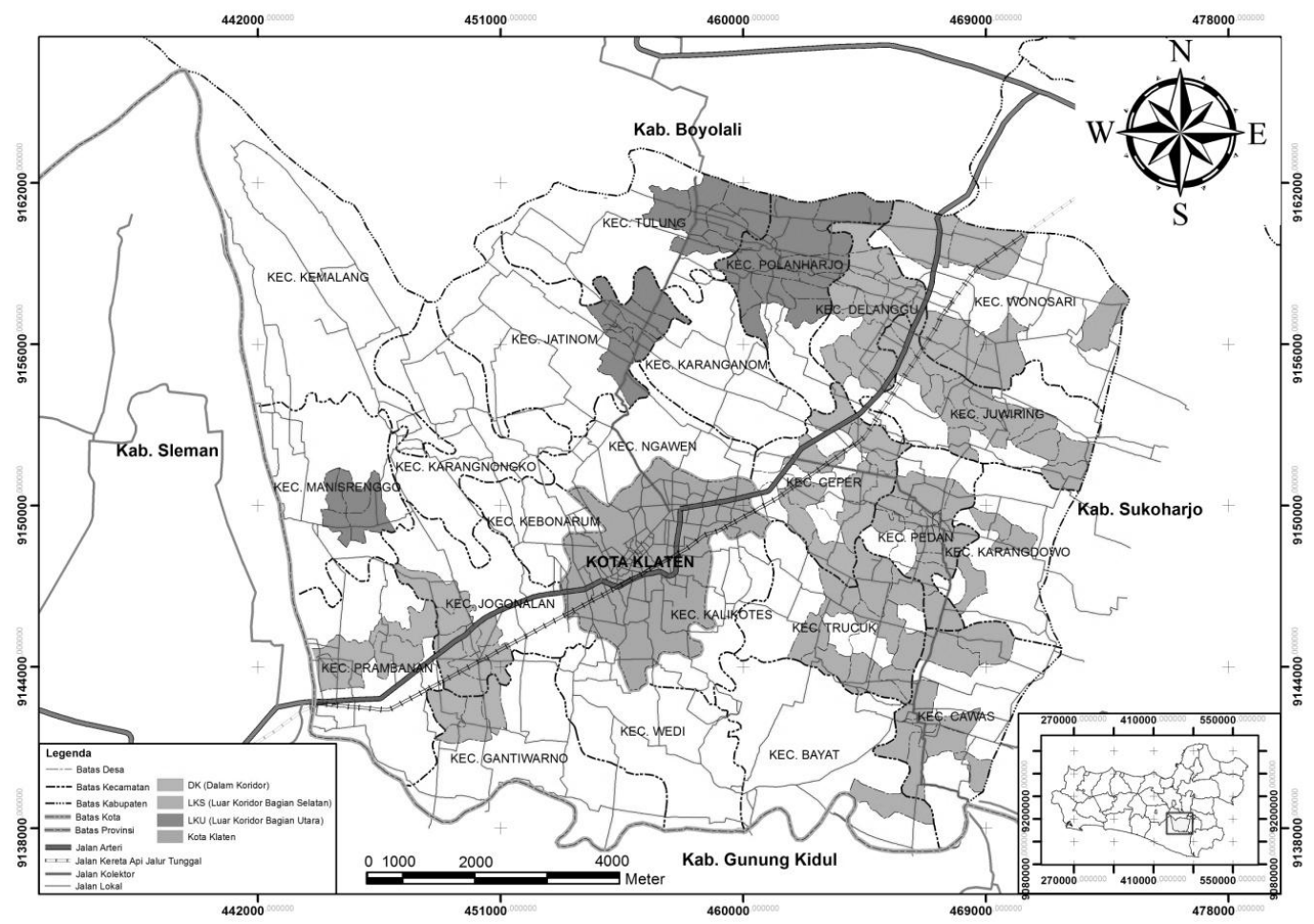

Figure 1. The Map of Research Study PUA in Klaten-Central Java

(Bappeda and Analysis)

Klaten is regency located in Central Java Province that has a very significant development. The fact has been showed that the rate of built-up area in Klaten from 1999 to 2009 amounted to $43.56 \%$ (ranked 6 th in the city/regency of Central Java or the first in regency administrative of Central Java). Its contribution to the economy of Central Java is ranked 10th from the top (2.9\%) (Central Java in Figures 2000-2011 and RTRWP Central Java in 2010). This indicates that there has been a transition in Klaten. Hence, Klaten is used as a case study to comprehend the phenomenon of urbanization in small towns in Central Java as well as the potential development of the region.

The increase of the built-up area showed that the need of space for development is relatively high, both in the urban and rural area. The situation in Klaten rural area has changed quite significantly and the character is getting similar to those that has been defined as urban area. For example, on trading activity, there are modern shops that resemble distributions in urban areas. This phenomenon is happening in the rural-urban transition area in Klaten.

The approach used in this study is mixed method (quantitative and qualitative) with sequential explanatory strategy. On this strategy that precedence is the quantitative part and the qualitative part is from interview for verifying and supporting purpose.

In defining the typology of peri-urban areas in Klaten, to refer the division of PUA, this study used references from Yunus (2001) and Singh (2011). The PUA categorized into 4 typologies: 
1. Primary/ inner, this area directly border with built up of urban area;

2. Secondary, this area directly border with primary/ inner;

3. Rural/ outer, this area directly border with belt of periphery;

4. Belt of periphery, this area directly border with rural area.

The first step is to determine the classification of each variable and to sum for weighting (look at Table 1 and 2). The value in the classification is assumed that toward urban, the value is smaller (1) than

(4). Based on data, the classification is divided into 2 types:

1. Type I, a part of variables that referring Singh's, the range of value too and a part variables to use sturgess method.

2. Type II, over all the classification on each variable, range of value to use strurgess methods

\section{Range of valueeach variables $=($ value up-value down $) / 4$ areas}

Table 1: Classification of Variable to Create Typologies of PUA Type I

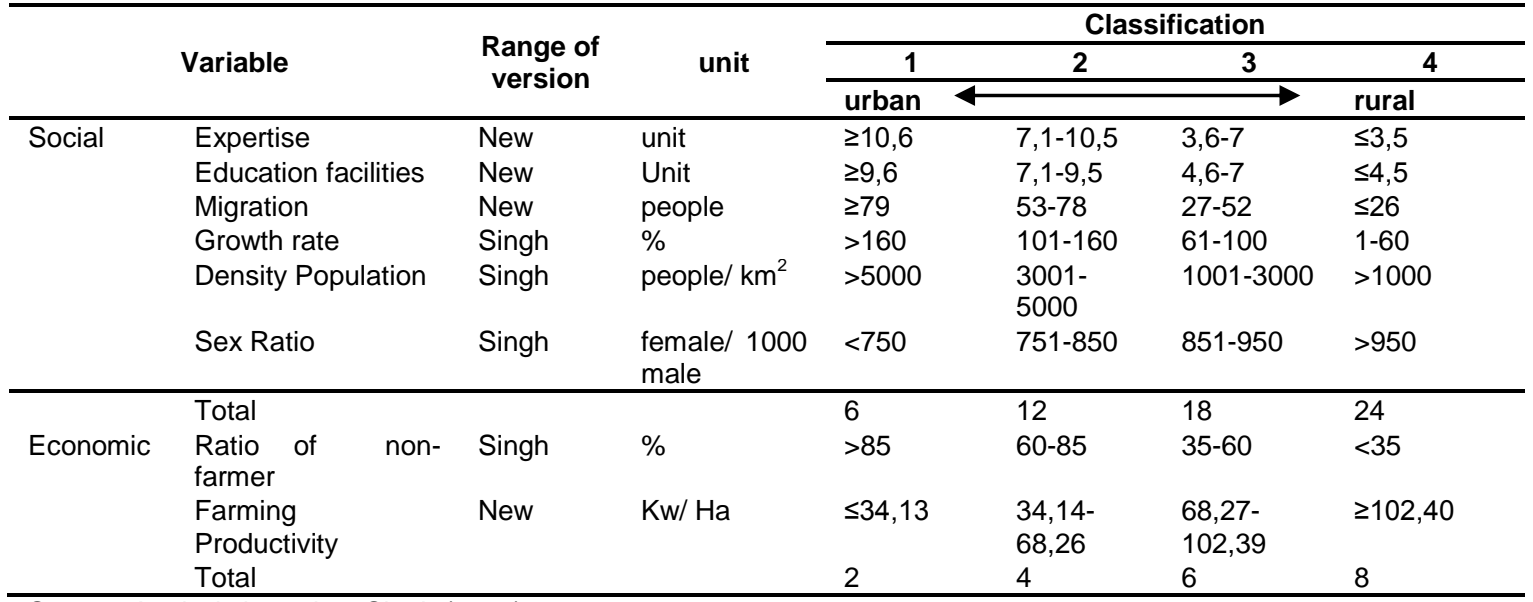

Source: Analysis based on Singh (2011)

Table 2: Classification of Variable to Create Typologies Of PUA Type II

\begin{tabular}{|c|c|c|c|c|c|c|c|}
\hline & \multirow{3}{*}{ Variable } & \multirow{3}{*}{$\begin{array}{l}\text { Range of } \\
\text { version }\end{array}$} & \multirow{3}{*}{ Unit } & \multicolumn{4}{|c|}{ Classification } \\
\hline & & & & 1 & 2 & 3 & 4 \\
\hline & & & & Urban & $\leftarrow$ & $\rightarrow$ & Rural \\
\hline \multirow[t]{6}{*}{ Social } & Expertise & New & Unit & $\geq 10,6$ & $7,1-10,5$ & $3,6-7$ & $\leq 3,5$ \\
\hline & Education facilities & New & Unit & $\geq 9,6$ & $7,1-9,5$ & $4,6-7$ & $\leq 4,5$ \\
\hline & Migration & New & People & $\geq 79$ & $53-78$ & $27-52$ & $\leq 26$ \\
\hline & Growth rate & New & $\%$ & $\geq 2,90$ & $1,41-2,89$ & $-0,09-1,40$ & $\leq-0,08$ \\
\hline & Density population & New & $\begin{array}{l}\text { People/ } \\
\mathrm{km}^{2}\end{array}$ & $\geq 4706$ & $\begin{array}{l}3560- \\
4705\end{array}$ & 2494-3599 & $\leq 2493$ \\
\hline & Sex Ratio & New & $\begin{array}{l}\text { Female } \\
1000 \text { Male }\end{array}$ & $\leq 888$ & $889-1009$ & $1010-1131$ & $\geq 1132$ \\
\hline \multirow{4}{*}{ Economic } & Total & & & 6 & 12 & 18 & 24 \\
\hline & Ratio of non-farmer & New & $\%$ & $\geq 77$ & $53-76$ & $29-52$ & $\leq 28$ \\
\hline & $\begin{array}{l}\text { Farming } \\
\text { productivity }\end{array}$ & New & $\mathrm{Kw} / \mathrm{Ha}$ & $\leq 34,13$ & $\begin{array}{l}34,14- \\
68,26\end{array}$ & $\begin{array}{l}68,27- \\
102,39\end{array}$ & $\geq 102,40$ \\
\hline & Total & & & 2 & 4 & 6 & 8 \\
\hline
\end{tabular}

Source: Analysis based on Singh (2011)

Note:

- $\quad$ Range of version-Singh: to refer on value is used Singh

- Range of version-New: determining range with used Sturgess method

The next step is weighting. It is to make criteria by ranges of each classification.

Table 3: Criteria of PUA Typologies based on Social and Economic Perspective

\begin{tabular}{|c|c|c|}
\hline Perspective & Typology & Range \\
\hline \multirow[t]{3}{*}{ Social } & 1 & $\leq 10,5$ \\
\hline & II & $10,6-15$ \\
\hline & III & $15,1-19,5$ \\
\hline \multirow[t]{2}{*}{ Economic } & I & $\leq 3,5$ \\
\hline & II & $3,6-5$ \\
\hline
\end{tabular}




\section{Analysis and Result}

\subsection{Typologies of PUA based on Social Perspective}

The typologies are resulted from the overlay maps and weighting. PUA in Klaten based on social perspective type I is included in the 3rd and 4th typologies. This indicates that the PUA rural character is stronger than urban. The majority of villages in all PUA are included as fourth typology. Approximately in DK of PUA is 40 villages (89\%), LKU is 25 villages (89\%) and LKS is 41 villages (93\%).

Typology of PUA in Klaten based on social perspectives for type II was also the same as type I, which most of the entry are in the 3rd and 4th typologies. Approximately in DK of PUA is 31 villages (69\%), LKU is 17 villages (61\%) and LKS is 24 villages (55\%). So, although using the Sturgess classification, the typologies of PUA in Klaten have values that similar with the mixed Singh classification.

\subsection{Typologies of PUA based on Economics Perspective}

The result of economics perspective type I represent that PUA in Klaten majority is classified into the 3rd and 4th typologies. This is to indicate the PUA character toward urban. The economics perspective contrast with social perspective. In PUA of DK, the majority of villages included in the typology II is about 28 villages (62\%), partly included in the typology III about 11 villages (24\%), and 6 villages included in the typology I (13\%). The PUA of LKU is similar to the PUA of DK that the majority of the villages including the village typologies III about $23(82 \%)$ and partly dispersed as a type I and II respectively of 2 villages (7\%) as well as 1 village typology IV (4\%). At WPU LKS, the villages that more into the typology III are 23 villages (52\%), typology II has 16 villages (36\%), and the rest goes in the typology I and IV.

The type II shows that the PUA in Klaten are dominated by typology II and III, except DK of PUA that is more dominated by typology I and II. In DK PUA, the majority of villages included in the typology II is 27 villages (60\%) and partially included in typology I is 15 villages (33\%). WPU LKU, typology II and III are more dominant which include 15 villages (54\%) in typology II and 7 villages (25\%) in typology III. In LKS PUA, typology II and III almost have equal distribution, i.e each of 17 villages (39\%) and 14 villages (32\%) and the first typology is 11 villages (25\%).

\subsection{The Elaboration of Typologies based on Socio-Economic Perspective of PUA in Klaten}

The typologies of social and economics will be elaborated by dividing the character of PUA into 4 groups, including Quadrant I until IV.

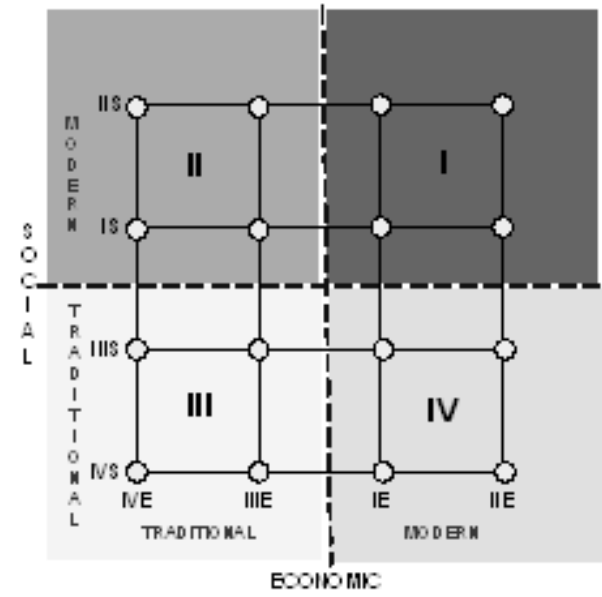

Figure 2. Quadrant of Typologies Elaboration Socio-Economic Perspective of PUA in Klaten

Note:

- I (Primary/ Inner): Modern Social (IS, IIS), Modern Economic (IE, IIE)

- II (Secondary): Modern Social (IS, IIS), Traditional Economic (IIIE, IVE)

- III (Rural/ Outer): Traditional Social (IIIS, IVS), Traditional Economic (IIIE, IVE)

- IV (Belt of Periphery): Traditional Social (IIIS, IVS), Modern Economic (IE, IIE)

The term of modern and traditional taken from development stage. The characteristics are:

1. The modern social perspective: individualist, Social modern perspective: Low social interaction (individualist), existence of social organization, able to cope with high technology, low social control, high mobilization, and low relationship system.

2. The modern economic perspective: Heterogenic occupation and not only from agriculture but more into trade, hotel and restaurant, and manufacturing industry sector.

3. The traditional social perspective: The relationship system is very high (paguyuban), institutional limitation, limited of technological capabilities, higher social control, and low mobilization.

4. The traditional economic perspective: Homogenous occupation, agricultural sector preference.

Condition of WPU in Klaten based on typologies represents a unique character because mostly the social perspective is more into rural characters (traditional), but economically it has urban characters (modern). The result of elaboration can be seen in Table 4 and Figure 3 until 4. 
Table 4: The Result of Typologies Elaboration Socio-Economic Perspective of PUA in Klaten

\begin{tabular}{|c|c|c|c|c|c|c|c|c|c|}
\hline \multirow[b]{3}{*}{ Typologies } & \multirow[b]{3}{*}{ PUA } & \multicolumn{8}{|c|}{ Elaboration Typology Socio-Economic Perspective } \\
\hline & & \multicolumn{2}{|c|}{$\mathrm{I}$} & \multicolumn{2}{|c|}{ II } & \multicolumn{2}{|c|}{ III } & \multicolumn{2}{|c|}{ IV } \\
\hline & & $\begin{array}{l}\begin{array}{c}\text { Number } \\
\text { of } \\
\text { Villages }\end{array}\end{array}$ & Percentage & $\begin{array}{l}\text { Number } \\
\text { of } \\
\text { Villages }\end{array}$ & Percentage & $\begin{array}{l}\text { Number } \\
\text { of } \\
\text { Villages }\end{array}$ & Percentage & $\begin{array}{l}\text { Number } \\
\text { of } \\
\text { Villages }\end{array}$ & Percentage \\
\hline \multirow{3}{*}{ Type 1} & DK & 1 & $2 \%$ & 0 & $0 \%$ & 2 & $4 \%$ & 42 & $93 \%$ \\
\hline & LKU & 0 & $0 \%$ & 0 & $0 \%$ & 15 & $54 \%$ & 13 & $46 \%$ \\
\hline & LKS & 0 & $0 \%$ & 0 & $0 \%$ & 14 & $32 \%$ & 30 & $68 \%$ \\
\hline \multirow{3}{*}{ Type 2} & DK & 0 & $0 \%$ & 0 & $0 \%$ & 3 & $7 \%$ & 42 & $93 \%$ \\
\hline & $\overline{L K U}$ & 0 & $0 \%$ & 0 & $0 \%$ & 11 & $39 \%$ & 17 & $61 \%$ \\
\hline & $\overline{L K S}$ & 1 & $2 \%$ & 0 & $0 \%$ & 16 & $36 \%$ & 27 & $61 \%$ \\
\hline
\end{tabular}

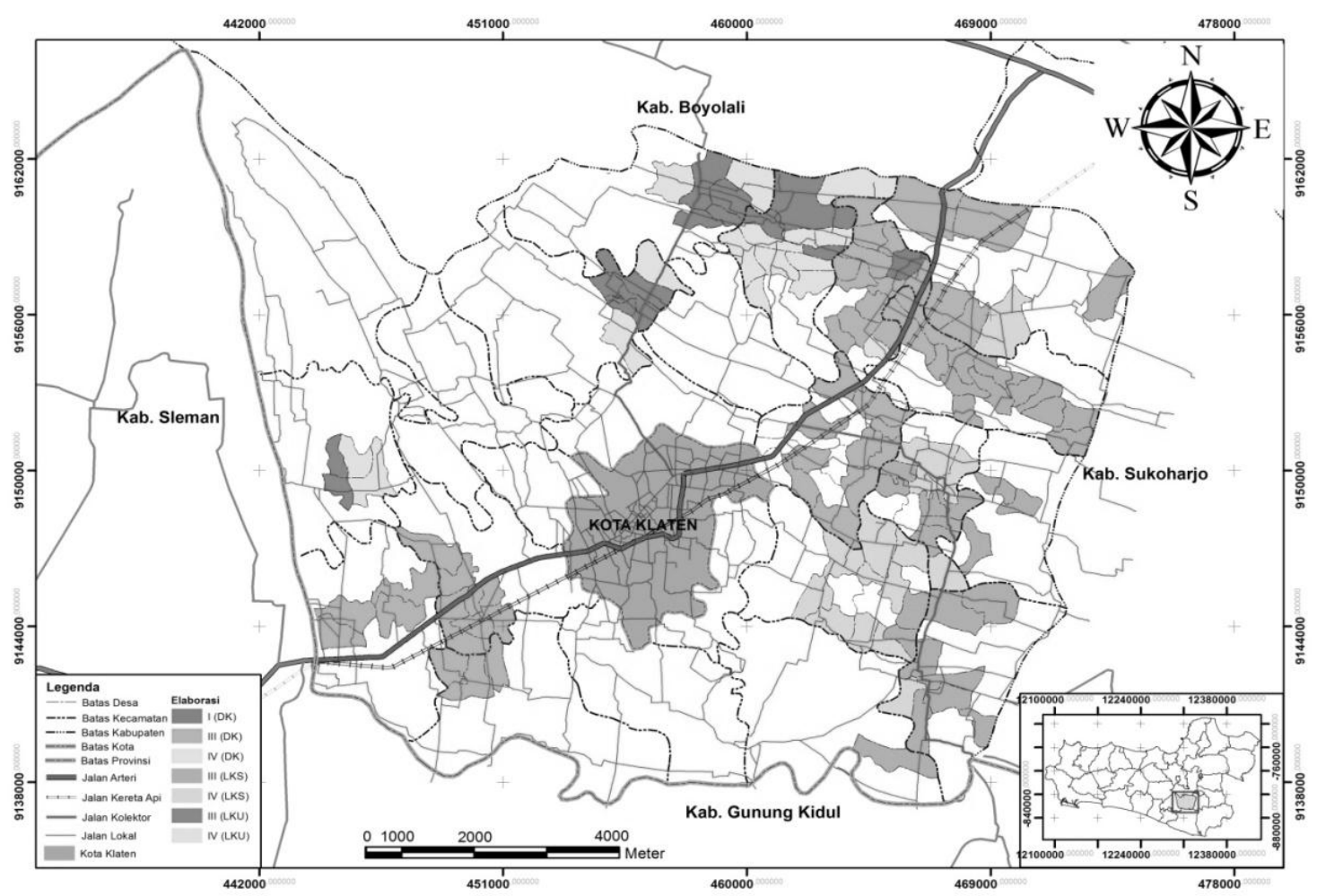

Figure 3. The Map of Typologies Elaboration

Based on Socio-Economic Perspective of PUA in Klaten Type 1

The result of typology based on social and economic perspective, both for type I and II, are dominated in typology IV. For DK PUA, both of the two types are dominated in typology IV (93\%). LKU PUA, the proportion in both of type I and II have contrary results. The typology III (54\%) in type I outnumbered typology IV (46\%), while in type II there are more into typology IV $(61 \%)$ than typology III (39\%). The proportion of typology in LKS PUA, both of type I and II are more dominated by typology IV $(>60 \%)$ than typology III $(<40 \%)$.

Although the result has dominancy in typology IV, but in this WPU there is village that included in the typology I. For the type I: The Typology I in DK PUA is Gatak Village (Delanggu District), for as type II: typology I is located on LKS PUA, there is Cawas Village (Cawas District). So, both of area have social character and economic character. Totally, the proportion of WPU includes into typology I, both of type I and II (1\%).

Typology II: there is not any single included in this typology. Typology III on the type I has 31 villages $(26 \%)$ and type II has 30 villages (26\%). Typology IV in the type I approximately has 85 villages (73\%) and type II about 86 villages (74\%). Therefore, there is no significant difference between type I and II. Dominancy of PUA in Klaten is still in typology IV (belt of periphery). 


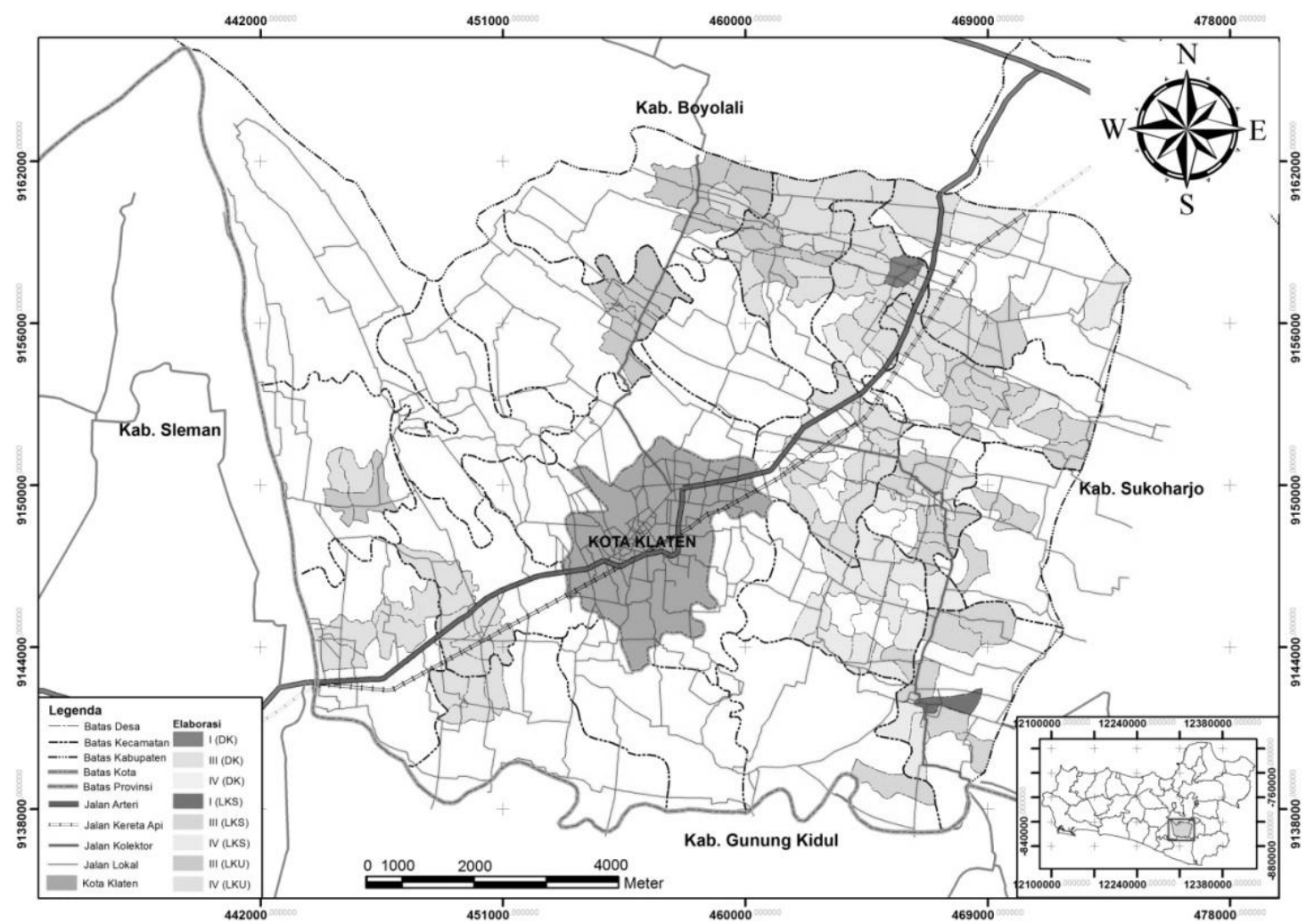

Figure 4. The Map of Typologies Elaboration Based on Socio-Economic Perspective of PUA in Klaten Type 2

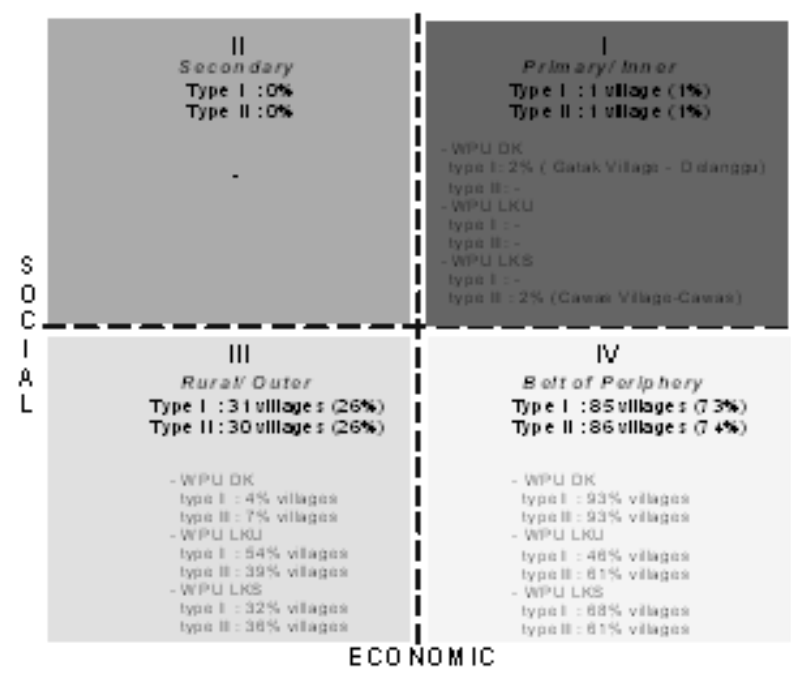

Figure 5. The Sintesys of Typologies Elaboration Based on Socio-Economic Perspective of PUA in Klaten

Typology I has interpretation that socially has more rural characteristic. It is characterized by decreasing social interaction because each person is busy with his occupation and economically can be seen from the heterogeneity of occupation in this area.

Typology II is characterized by the presence of mindset that is affected by the urban areas, even though the economic occupation characteristic is still in homogenous.

Typology III has social and economic characteristics of rural (traditional), such as the high society interaction, but the mindset and activities from society are homogeneous.

Typology IV is contrast from typology II, i.e the economic characteristic is stronger than social side. It is to represent the higher competitiveness of this area because the strong existence of local economic in this area. And this area is still classified as rural. 


\section{Conclusion and Recommendation}

The results of the analysis have shown that most of villages in the study area are highly rural in terms of social character. On the contrary, in economic aspect such as employment, the PUA of Klaten community has a strong urban character. It is classified as the fourth typology (highly rural in social character and highly urban in economic character) among the four identified PUA typologies in Klaten. Threfore, the condition of PUA in Klaten can be mentioned as growing villages.

The typologies in PUA Klaten are to some extent different with typologies developed by Singh (2011) in Varanasi-India. Typologies in Varanasi-India are very much considered distance as the main indicator. It indicates that the farther from center then that area will have rural typology. Meanwhile, typologies PUA in Klaten do not depend on range from the city center.

The underlying influential factor of the development of PUA in Klaten is very much its local potential (44\%), i.e. the local economic activity. This may provide an evidence that urban and rural growth could be taken place as a part of 'local' growth which does not necessarily take place as a part of urban growth (expansion of Yogyakarta - Surakarta) as the main city (growth center). Recommendation for further development to each typology can be seen in Figure 6.

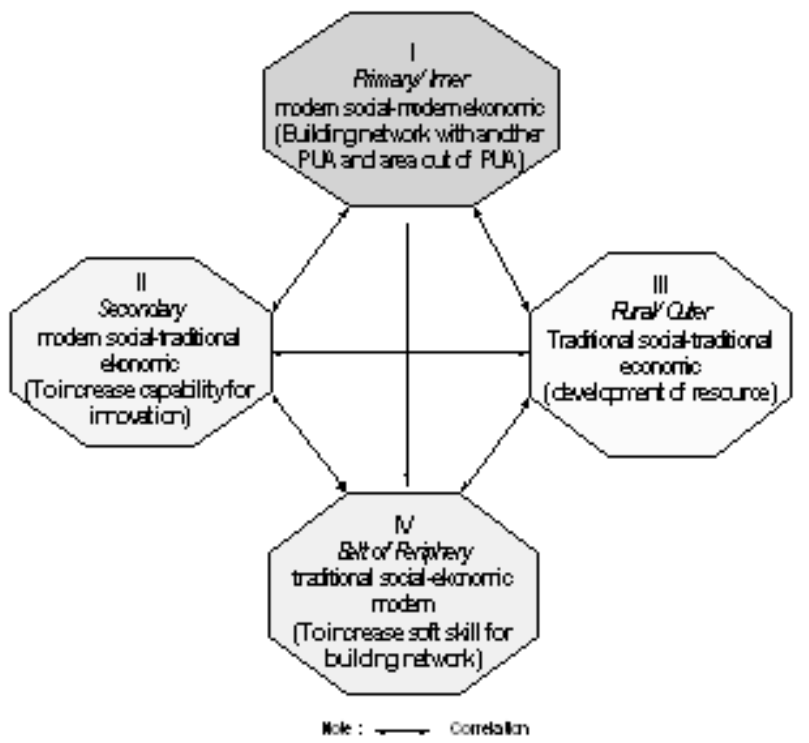

Figure 6. Recommendation of Development of PUA based on Typologies and Existance Local Potention

\section{References}

Bintarto, R. (1984). Urbanisasi dan Permasalahannya. Jakarta: Ghalia Indonesia

Champion, T., \& Hugo, G. (Eds.). (2004). New forms of urbanization. Cornwall: International Union for the Scientific Study of Population (IUSSP).

Daldjoeni, N. (1992). Geografi Baru: Organisasi Keruangan dalam Teori dan Praktek. Bandung: Penerbit Alumni

Damanik, Janianton. (2003). Urbanisasi Tanpa Transformasi Sosial Ekonomi. Fakultas Ilmu Sosial dan IImu Politik Jurusan IImu Kesejahteraan Sosial Universitas Sumatera Utara. [Home page of Forum TI ITS] [Online]. Available at: www.netseminar.tripot.com. Diakses pada tanggal 22 Mei 2012

Firman, Tommy, Kombaitan, Benedictus and Pradono. (2007). The Dynamics of Indonesia's Urbanisation, 1980-2006. Urban Policy and Research, 25: 4, 433 - 454, First published on: 10 October 2007 (iFirst)

Handayani, Wiwandari dan Iwan Rudiarto. (2011). Dinamika Persebaran Penduduk Jawa Tengah: Perumusan Kebijakan Perwilayahan dengan Metode Kernel Density. 2011. Vol 222-219

Handayani, Wiwandari et al. (2012). Dinamika Perkembangan Wilayah Peri-Urban pada Kota KecilMenengah di Kabupaten Klaten. Program Magister Pembangunan Wilayah dan Kota, Fakultas Teknik Universitas Diponegoro. Semarang

Herlianto. (1997). Urbanisasi, Pembangunan, dan Kerusuhan Kota. Bandung: Penerbit Alumni

Hugo, Graeme. (2003). Urbanisation in Asia: An Overvie. Australia: Paper prepared for Conference on African Migration in Comparative Perspective, Johannesburg, South Africa, 4-7 June, 2003.

Kuncoro, Mudrajat. (2002). Analisis Spasial dan Regional. Yogyakarta: AMP YKPN

Leeuwen, Eveline S. van. (1993). Urban-Rural Interactions: Towns as Focus Points in Rural Development. London New York: Heidelberg Dordrecht

Nas, PJM. (1979). Kota di Dunia Ketiga: Kota dalam Berbagai Kawasan, Budaya dan Masa. Jakarta: Bhratara Karya Aksara

Pacione, Michael. (2001). Urban Geography: A Global Perspective. London: Routledge.

Santoso, Singgih. (2000). Buku Latihan SPSS Statistik Parametrik. Jakarta: PT. Elex Media Komputindo 
Singarimbun, Masri dan Sofian Effendi. (1989). Metode Penelitian Survai. Jakarta: LP3ES

Singh, Rana P.B. (2011). Changing Rural Landscapes in The Peri-Urban Zone of Varanasi and Strategies for Sustainable Planning dalam International Symposium: Sustainable Rural Landscape and Planning in Asia Pasific Region. Prosiding International Symposium "Sustainable Rural Landscape and Planning in Asia Pacific Region. IFLA APR Cultural Landscape Committee dan Korean Society of Rural Planning. December 5th - 8th 2011. Seoul - Korea Selatan.

Soetomo, Sugiono. (2002). Dari Urbanisasi ke Morfologi Kota: Mencari Konsep Pembangunan Tata Ruang Kota yang Beragam. Semarang: Badan Penerbit Universitas Diponegoro

Sugiana, Kawik. (2005). "Keterkaitan Desa-Kota di Indonesia." Bunga Rampai Pembangunan Kota Indonesia dalam Abad 21, Konsep dan Pendekatan Pembangunan Perkotaan di Indonesia. Jakarta: Lembaga Penerbit Fakultas Ekonomi UI.

Sugiarto, dkk. (2003). Teknik Sampling. Cetakan ketiga. Jakarta: Gramedia Pustaka

Tarigan, Robinson. (2004). Perencanaan Pembangunan Wilayah. Jakarta: PT. Bumi Aksara

Yunus, Hadi Sabari. (2000). Struktur Tata Ruang Kota. Yogyakarta: Pustaka Pelajar

Yunus, Hadi Sabari. (2006). Megapolitan: Konsep, Problematika dam Prospek. Yogyakarta: Pustaka Pelajar

Yunus, Hadi Sabari. (2008. Dinamika Wilayah Peri-Urban: Determinan Masa Depan Kota. Yogyakarta: Pustaka Pelajar

Yesiana, Reny. 2006. "Sistem Distribusi Komoditas Pasar dan Dampaknya terhadap Pengembangan Kawasan Bandungan". Tugas Akhir tidak diterbitkan, Jurusan Perencanaan Kota Wilayah dan Kota, Fakultas Teknik Universitas Diponegoro, Semarang 